\title{
The Constraints of Rural Women in Informal Economic Activities in Imo State, Nigeria
}

\author{
Emmanuella Chinenye Onyenechere
}

\begin{abstract}
The paper analyzes the constraints on rural women in the informal sector of Imo State, Nigeria. Lack of access roads, irregular means of transportation, inadequate credit facilities, inaccessibility to socio-economic facilities and land tenure are identified as among the factors that have adverse effects on the participation/activities of rural women engaged in informal economic activities in the rural areas of Imo State. The paper further reveals that a majority of rural women in Imo State, engaged in informal economic activities, do not have significant access to institutional finance, neither do they for socio-economic services that could enhance women's informal economic activities. The paper eventually makes policy recommendations to help alleviate women's difficulties in the informal sector.
\end{abstract}

\section{Résumé}

Cet article analyse les contraintes des femmes rurales dans le secteur informel de l'État d'Imo au Nigeria. Le manque de routes d'accès, l'irrégularité des moyens de transport, l'insuffisance des structures de crédit, l'inaccessibilité des structures socio-économiques et le régime foncier ont été identifiés comme étant parmi les facteurs qui ont des effets néfastes sur la participation/les activités des femmes rurales engagées dans des activités économiques au niveau des zones rurales de l'État d’Imo. L'article révéle aussi que la majorité des femmes rurales dans l'État d'Imo engagées dans des activités économiques informelles n’ont pas un accès considérable à des financements institutionnels ni à des services socio-économiques qui pourraient améliorer leurs activités économiques informelles. Cet article donne aussi des recommandations politiques quant aux moyens d'alléger les difficultés rencontrées par les femmes dans le secteur informel.

* Lecturer, Department of Geography and Environmental Management, Faculty of Environmental Sciences, Imo State University, Owerri, Nigeria. E-mail:emmazob@yahoo.com. 


\section{Introduction}

Decades of stifling structural adjustment programmes coupled with austerities of neoliberal economic reforms have led to a worsening of economic problems in recent times. And the globalization of culture, capital, and information has had a significant influence on the informal sector. For one thing, women in rural areas, who would ordinarily be housewives alone in their own right and locality, are increasingly forced by economic downturns to participate in informal economic activities in search of income to support their families or even to become breadwinners. In certain cases, a rural woman in the village might herself be compelled to rely on the labour of unpaid family members, especially that of children. While men migrate out of the rural areas for urban centres to seek better livelihoods to maintain their families, migrant fathers have to leave their children behind under the care of their wives.

Mate's (2005) study affirms that in the face of male migration, women are left to take care of houses, cattle and children in town or rural homesteads, Her study also affirms that when a husband's money falls short, very often the wife is forced to get an informal sector job. This perhaps explains why as a consequence of enduring sharp economic downturns mothers and wives enter the workforce to make ends meet and support families following their husbands who as sole breadwinners, had migrated, suffered wage cuts, or been fired.

Presently, there is an upsurge of female-headed households in the Nigerian hinterlands or the rural areas of most regions, occasioned by globalization. This is to say that, theoretically, women's activities in the informal sector enable them to effectively combine their productive and reproductive roles because hours of work are flexible, permitting women to care for their children. It is notable, however, that while there is a high status of men and their economies of masculinity, women's collective subordination as a social class under masculine structures of domination points to the confinement of the role of women to that of primary caregivers and parents with daily responsibility for children in the society. Even the very fact of having to depend on men at times to seek autonomy reinforces the subordination that denies women their status as social and economic actors in their own right and in their own terms.

It must be emphasized that the informal sector, which today is being gradually dominated by women, derives from globalized capitalist structures of and assumptions about gender and power that have tended to prescribe and legitimate the public sphere for men, while confining women's activities and capabilities to the private sphere and the less visible zones of the public 
workplace. This implies that while men are free to seek employment and harness possibilities outside of the home, women are generally constrained by domestic chores and minor informal sector activities from which they can only graduate fully or temporarily by compounding the subjection of fellow women or even children who act as unpaid labour in family businesses. These facts suggests that globalization is a highly hierarchical and inegalitarian process affecting individuals and communities differently as informed by gender and geography (Nyamnjoh 2005a).

In an environment of neoliberal economic reforms in Nigeria increasing poverty has rendered female participation in rural informal economic activities an emerging livelihood strategy. Thus women's increasing participation in the informal sector arises from the current economic hardship in Nigeria and the fallout of the Structural Adjustment Programme (SAP). More than before, women are under increasing pressure to contribute to household income; this is even more true of women whose husbands have been laid off by the formal sector as a result of rationalization, privatization of public enterprises, and cuts in government spending (Soetan 1993).

Females in Nigeria's informal sector seem to be invisible, along with their contributions and needs, given that the prevailing soical system has a, patriarchal context in which women seek and access social opportunities (Nyamnjoh 2005b). Gender inequalities are persistent, a situation corroborated by Arnfred (2004), who states that 'women are denied the recognition and representation they seek for their complex identities and sexualities'. Women thus, although disadvantaged by gender, the access to needed resources and production inputs of rural men, are used to further institutionalize social inequalities and silences over the rights of rural women in the informal sector. As long as states, laws and cultures continue to be paternalistic, nurturing and glorifying men and boys at the expense of women and girls, they must realize that women will always feel relegated to the background, especially when even while grappling with the realities that informal sector activities usually have low returns, some people view women who work in the informal sector as loose. Mate's (2005) study revealed that informal sector activities are sometimes perceived or seen as an embarrassing attempt at resolving poverty. She explained that in Zimbabwe, for men especially, when wives participate in informal sector activities it is considered an indictment of one's masculinity. It suggests that the man is incapable of looking after his family. It is obvious that these latter dimensions are far from being complimentary for womenfolk in Zimbabwe, Nigeria or elsewhere.

Rural women's informal economic activities are an integral component of the rural economies in Nigeria, including Imo State. Imo State embodies 
both agricultural and non-agricultural activities by rural women in the rural areas. Non-agricultural activities include traditional crafts, modern crafts, small-scale distribution, and tertiary activities such as hairdressing, photography, and transport operations. These are predominantly small-scale production and service activities. Imo State is largely made up of rural villages, which constitute most of its population, and the rural women of the state have resorted to various sources of livelihood such as farming, fishing, and trading. Women's informal economic activities constitute the single most important source of employment in rural Nigeria. Abumere (1995) described them as invisible, irregular, backyard, underground, unorganized, black, murky, subterranean, hidden, shadow, clandestine, illegal, unobserved, unreported, unrecorded, second, residual, and unenumerated. However, they employ between 40 and 60 percent of the labour force and contribute between a quarter and a third of incomes in most African countries (International Labour Organization 1985). As a result of the diminished economic status of women, they are seldom able to explore and exploit emerging opportunities for higher incomes. This makes their access to formal sector funds minimal (Federal Government of Nigeria 1993; Damson and Oyeyinka 1993).

The agricultural labour force makes up almost two-thirds of the economically active population in Imo State, and rural women working informally are a significant part of the total. Additionally, the effect of neoliberalism is increased informal sector activities. The notion of the informal economic sector for this study captures certain peculiarities, such as informality of business organization, use of rudimentary technology, lack of separation of consumption and production, ease of entry and exit, reliance on family labour and apprentices, and small requirements for capital. UNECA/ AAPAM (1992) defined the informal sector as those small-scale incomegenerating activities that are not registered under law, do not comply with legislated standards of quality, minimum pay and safety, and, more often than not, do not pay taxes. The informal sector is synonymous with informal economic activities, the real sector, the economy of the poor, petty commodity producers and micro enterprises (Gerry 1978; Hemmer and Manuel, 1989; McNeil 1993; Obadan et al. 1996). The importance of this economic sector to the rural women in Imo State cannot be over-emphasized.

The problems confronting rural women in informal economic activities relative to rural development are manifold. For instance, Ijere (1992) found that commercial banks and government agencies are unsympathetic to women seeking funds to set up income-yielding ventures, and the women themselves lack initiative because they are reluctant to exert themselves, tending to abdicate their responsibilities and rights to men, especially in male-headed households. 
In general, informal economic activities in the rural parts of developing countries such as Nigeria may be said to encounter problems that range from communication to socio-economic facilities, which are associated with low production and returns. For example, Ogundana (1970), Aluko (1980) and Ogbonna (1988) recognized the severe mobility deficiencies found in rural areas and stressed that where there are no means of transportation, the will to produce more for sale will be stifled, and even when more is produced it is bought by itinerant traders at prices much lower than can be charged in the towns.

In addition, it is observed that lack of working capital and finance to expand investment is the most general constraint affecting informal sector activities in Nigeria - 76.4 per cent of entrepreneurs considered it their major problem (FGN 1993). Various studies have revealed that over half of the finance for initial investments and expanding capital comes from personal savings (FGN 1993; Damson and Oyeyinka 1993), and also from contributions and borrowing from friends and relatives (Odurukwe and Okorji 2002). Minimum access to formal sector funds is consistently mentioned as a related major problem.

Other studies by Saitao and Spurning (1992), and Eze and Okoli’s (1995) study in Nsukka as well as Eze's (2002) study in Anaocha LGA of Anambra State have blamed poor food producing and processing activities on limited dissemination of agricultural technologies. In Eboh and Ocheoha (2002), evidence from Enugu State showed that rural people expressed concern about the severe debilitating constraints on their non-farm enterprises. These included shortage of initial and operation capital (89 per cent), lack of access to requisite credit (85 per cent), high cost of enterprise establishment/operating (72 per cent), poor and sometimes non-existent infrastructure (81 per cent), scarcity of inputs or raw materials (60 per cent) and lack of information, knowledge and access concerning productivity-enhancing technologies (58 per cent).

Again, there are problems such as poor marketing systems and competition from protected formal sector firms. These have constituted the major demand problems in informal sector activities in Nigeria. Increased competition and reduced demand are seen as central problems of the informal sector while lack of market space is a particularly acute problem for transporters and retail wood workers (Damson and Oyeyinka 1993). Obadan et al. (1996) also noted that problems arising from government regulations included heavy taxes, harassment from local authorities, imposition of certain standards on the production of goods and services, and unclear laws and regulations.

Provision of infrastructural facilities is another problem, making the rural environment unattractive to the young, and leading to migration. Anozie and 
Onwumere (1988) and Igbozurike (1985) found that rural electrification and water supply are critical variables in rural development. Specifically, there is the problem of land tenure. Land ownership is the primary determinant of degree of wealth, level of social welfare, access to power, and, in many instances, even survival (Igbozurike 1986; Barlowe 1978; Crowley 1995). Yet, according to Nwebo and Eze (1989), the rural poor - peasant farmers, farm workers, fishermen, rural women - are all deprived of rights, including access to land, which we consider basic to their material existence and selfrealization.

Considering all such constraints, Olayide et al. (1975) offer a fivefold classification of the difficulties: natural problems, socio-cultural problems, politico-administrative problems, organizational problems, and economic problems. They also point out that rural-based enterprises are marked by smallness of scale and primitive, cultural and poor management practices. On the other hand, the argument of FAO (1999) is that providing women with secure and effective access to land and other variables can benefit families, communities and countries through increased economic opportunities; increased investment in land and food production; improved family security during economic and social transitions; and better land stewardship. It is worth mentioning here that some gender-based studies, including those by Dietrich (1995), Malunga (1998), Feldman (1991), Brand et al. (1995) and Goodale (1989), have contested the challenges to women's involvement in the informal sector. According to Dietrich (1995), the fact that women are in the forefront of this struggle indeed means that the focus is on the right to life and livelihood.

It is the aim of this study to examine the problems and prospects of informal economic activities in the development process of rural areas by rural women in Imo State. It has the following objectives: (1) to identify the types of informal economic activities engaged in by rural woman; (2) to identify the constraints faced by rural women in their informal economic activities; and (3) to make recommendations geared towards the improvement of rural women's work in the informal sector. Through such research, we obtain better insights into the dynamics of persistent gender inequalities and the challenges of the rural informal sector in Nigeria. The study will aid policy formulation for informal sector activities and poverty alleviation of women in rural areas, which will in turn contribute to the improvement of the welfare of the rural population and assist government in channelling its activity in the rural areas, leading to the mobilization of women for the economic reactivation of Imo State. 


\section{Materials and Methods}

\section{Sampling Procedure}

For the purpose of this study, the first sampling procedure was to obtain a list of Local Government Areas (LGAs) in Imo State and their political division. There are 27 LGAs in Imo State, politically divided into the three senatorial district (SD) or geopolitical zones of Orlu, Owerri and Okigwe. Each senatorial district was taken as a stratum in the stratified sampling frame. The rationale for using the SDs as strata was to ensure equitable coverage so that the peculiarities of each zone are captured in our survey.

In each stratum, the LGAs were arranged alphabetically and systematically selected at intervals of three, giving a sample of nine LGAs for the purpose of administering the questionnaire. The number of LGA sampled from each stratum was in proportion to the number of local governments in the SD. Thus, from Orlu Zone, with 12 LGAs, Owerri with nine and Okigwe with six, the numbers of sampled local governments were four, three and two respectively.

Within each sampled LGA, two communities were randomly selected using the table of random numbers. In all, 18 autonomous communities were covered by the survey. It is to be noted that each local government area and each community serve as a stratum so that the emergent technique is best described as a randomized systematic stratified sampling technique. The rationale for stratified sampling was to utilize the expertise of Schaffer, Mendenhall and Ott (1979) who articulate that 'stratified sampling often results in increased information for a given cost'. They contend that the data are more homogeneous within each stratum than in the population as a whole, plus the added advantage that separate estimates of population parameters can be obtained for each stratum without additional sampling. For a study within a defined geographical milieu, the randomized systematic stratified sampling is viewed as relevant and appropriate.

\section{Source of Data and Analytical Techniques}

Data for this study were derived from mainly primary sources. These were obtained by using a well-structured 48-item questionnaire, which was augmented with focus group discussion sessions. The respondents for the research were the rural women who engaged in informal sector activities.

Therefore, the information provided by these women formed the majority of the primary data including direct field observation. It is noteworthy that the data equally provided useful information on the socio-economic status of the rural women, various types of informal economic activities by the women and the contribution of rural women to informal economic activities in the study area. 
Other sources of data included secondary data collected from journals, research reports and statistical records from the Ministry of Women Affairs and Social Development, the Bureau for Chieftaincy and Local Government Affairs, Departments of Finance in the sampled Local Government Council and National Population Commission. Information obtained was related to rural women and informal economic activities, especially the prevalent ones in the study state.

The primary data collected for this study were analyzed using descriptive and inferential statistics. Frequency distribution and percentages were used to plot tables from which Z-tests of proportion tests were employed to draw inferences about population parameters from appropriate sample estimates on specific constraints facing those rural women.

\section{Results and Discussion}

The various types of informal economic activities engaged in by the rural women in this study are shown in Table 1 below.

\section{Types of Informal Economic Activities of Rural Women}

Table 1 reveals that the rural women are engaged several informal economic activities. For this study only the predominant activity of the respondent was considered. The study revealed that a large proportion of respondents (39.7 per cent) were involved in petty trading. Farming, i.e. crop and animal husbandry, occupied 29.1 per cent of the respondents. Artisan/handicraft activities were not popular among rural women, and they accounted for 3.8 per cent. This could be related to scarce material inputs and lack of specialized skills required for artisan and handicraft activities. Rural women lacked such resources.

Problems identified as militating against rural women informal economic activities in this study are shown in Table 2.

\section{Table 1: Types of Informal Economic Activities of Rural Women}

\begin{tabular}{lcc}
\hline Types of Informal Economic Activities & Frequency & Percentage Frequency \\
\hline Farming & 680 & 29.1 \\
Food Processing & 640 & 27.4 \\
Artisan/Handicrafts & 90 & 3.8 \\
Petty Trading & 930 & 39.7 \\
\hline TOTAL & 2340 & 100.0 \\
\hline
\end{tabular}

Source: Author's fieldwork.

\section{Constraints on Informal Economic Activities}

Table 2 reveals that many problems confront informal economic activities in the study area. Generally the problems range from poor development of 
infrastructural facilities (roads, electricity, potable water et.c), and lack of credit facilities to small markets and land tenure problems that hinder development of large-scale farming. Out of 2,340 respondents 310, or 13.2 per cent, identified poor access roads as a constraint militating against their optimal performance; 4.3 per cent identified irregular means of transportation as a problem. Inadequate credit facilities were identified by 23.1 per cent, absence of socio-economic facilities by 3.0 per cent, land tenure (scarcity of farm land) by 7.7 per cent, and low capital by 17.5 per cent. Only 460 respondents out of a total of 2,340, or 19.7 per cent, identified poor development of infrastructure and 11.5 per cent low markets (see Table 2).

However, the intensity of these problems varies from community to community. On lack of access roads, Dikenafai (16.13 per cent), Isiekenesi (12.9 per cent), Nkwerre (12.9 per cent) and Owerre Nkwoji (12.9 per cent) communities of Orlu Zone are the most challenged. The only road linking Dikenafai and Isiekenesi to the Okigwe-Enugu Expressway is a dirt road, which is dusty and untarred. Similarly the only road linking OrluNkwerre-Owerre Nkwoji and finally joining the Okigwe-Enugu Expressway is riddled with potholes, which gives a bumpy ride and leads to frequent breakdown of cars plying the road. Communities less challenged by the lack of access roads are Enyiogugu (3.23 per cent), Ifakala (3.23 per cent), Otulu (3.23 per cent) and Umuna (3.23 per cent). Irregular means of transportation such as trekking (going by foot), use of bicycles and motor bikes for long-distance journeys as opposed to buses and cars were commonly cited in those communities constrained the most by lack of access roads. These irregular means of transportation hinder these women from moving their produce effectively: in Dikenafai 20 per cent are constrained, in Isiekenesi 10 per cent, and in Nkwerre 10 per cent. Others equally constrained by irregular means of transportation are women in Okuku (10 per cent), Orodo (10 per cent), Owerre Nkwoji (20 per cent) and Umuna (20 per cent).

Inadequate credit facilities constrain all the women in the study communities. However, communities such as Oguta (11.11 per cent), Nkwerre (9.26 per cent), Owerre Nkwoji (7.41 per cent), Umuna (7.41 per cent) and Amaraku (7.41 per cent) are the most challenged, while Enyiogugu, Ifakala, Isiekenesi, Mgbidi, Nguru Nwenkwo, Okuku, Orsu Obodo and Umunkwo are equally constrained at 5.56 per cent. Least constrained are Dikenafai (1.85 per cent), Okwelle (1.85 per cent), Orodo (3.7 per cent), Otulu (1.85 per cent) and Umuguma 53.7 per cent). Most of these study communities lack any micro-finance facilities, while many of the women do not posses the required collateral, especially land, with which to approach the bank. Only few communities have women constrained by absence of socioeconomic facilities. They are Ifakala (14.29 per cent), Nguru Nwenkwo 
(28.57 per cent), Okwelle (28.57 per cent), Otulu (14.29 per cent) and Umuguma (14.29 per cent). On the other hand, other study communities, namely Amaraku, Dikenafai, Enyiogugu, Isiekenesi, Mgbidi, Nkwerre, Oguta, Okuku, Orodo, Orsu-Obodo, Owerre Nkwoji, Umuna and Umunkwo, have the presence of schools, hospitals, post office and health facilities. While some communities have all the aforementioned socio-economic facilities and more, others have them in relative numbers.

Land tenure (scarcity of farmland) constrains women found in the densely populated communities studied. Those in Owerri Zone constrained by this factor are in Enyiogugu (11.11 per cent), Ifakala (5.56 per cent), Nguru Nwenkwo (11.11 per cent) and Orodo (11.11 per cent). In Okigwe Zone comparable results are found in Amaraku (11.11 per cent), Okwelle (5.56 per cent) and Umunkwo (11.11 per cent). On Orlu Zone the relative communities are in Mgbidi (5.56 per cent), Nkwerre (11.11 per cent), Orsu Obodo (5.56 per cent), Otulu (5.56 per cent) and Owerre Nkoji (5.56 per cent). The following communities had no respondents who identified land tenure as a constraint: Dikenafai, Isiekenesi, Oguta, Okuku, Umuguma and Umuna.

Almost all the women in the 18 study communities have the problem of low capital. The small scale of operation of women in rural informal sectors of the study area is occasioned by the low capital with which they operate. However, the intensity of this factor is higher for those in Amaraku (9.76 per cent), Mgbidi (9.76 per cent) and Otulu (976 per cent), perhaps because they are market towns on the major truck roads linking Imo State with other neighbouring states, wherein petty trade is highly concentrated. Poor development of other infrastructure, such as water and electricity, impedes the women of Umunkwo (10.9 per cent), Orsu Obodo (10.9 per cent), Okuku (8.7 per cent) and Ifakala (8.7 per cent) the most, in that order. Threshold population, also referred to as the low market factor, constrains those in Amaraku (3.7 per cent), Enyiogugu (7.41 per cent), Mgbidi (7.41 per cent), Nguru Nwenkwo (7.41 per cent), Oguta (14.81 per cent), Okuku (3.7 per cent), Okwelle (7.41 per cent), Orsu Obodo (14.81 per cent), Otulu (7.41 per cent), Owerre Nkwoji (3.7 per cent), Umuguma (7.41 per cent), Umuna (11.11 per cent) and Umunkwo (3.7 per cent).

In summary, while poor access roads are a significant problem in Dikenafai (16.3 per cent), this is a non-issue in Ifakala and Umuguma communities. Oguta community has the smallest number of factors (three) constraining rural women's informal economic activities in it., while Okwelle, Otulu and Umuguma have the greatest number of factors (seven) constraining rural women's informal economic activities in it. On the average there are six constraints facing the study communities, and of the 18 study communities eight are constrained by six factors. 
Table 2: Constraints on Rural Women's Informal Economic Activities

\begin{tabular}{|c|c|c|c|c|c|c|c|c|c|}
\hline Communities & $\begin{array}{l}\text { Lack of } \\
\text { Access } \\
\text { Roads }\end{array}$ & $\begin{array}{l}\text { Irregular } \\
\text { Means } \\
\text { of Trans. }\end{array}$ & $\begin{array}{l}\text { Inadequate } \\
\text { Credit } \\
\text { Facilities }\end{array}$ & $\begin{array}{l}\text { Absence } \\
\text { of Socio- } \\
\text { eco. Fac. }\end{array}$ & $\begin{array}{l}\text { Land } \\
\text { Tenure }\end{array}$ & $\begin{array}{l}\text { Low } \\
\text { Capital }\end{array}$ & $\begin{array}{l}\text { Poor Dev. } \\
\text { of Other } \\
\text { Infras. }\end{array}$ & $\begin{array}{l}\text { Low Mkt/ } \\
\text { Threshold } \\
\text { Population }\end{array}$ & Total \\
\hline Amaraku & 0 & 0 & 40 & 0 & 20 & 40 & 20 & 10 & 130 \\
\hline (\%) & 0 & 0 & 7.41 & 0 & 11.11 & 9.76 & 4.35 & 3.7 & 36.33 \\
\hline Dikenafai & 50 & 20 & 10 & 0 & 0 & 20 & 30 & 0 & 130 \\
\hline (\%) & 16.13 & 20 & 1.85 & 0 & 0 & 4.88 & 6.52 & 0 & 49.38 \\
\hline Enyiogugu & 10 & 0 & 30 & 0 & 20 & 20 & 30 & 20 & 130 \\
\hline (\%) & 3.23 & 0 & 5.56 & 0 & 11.11 & 4.88 & 6.52 & 7.41 & 38.71 \\
\hline Ifakala & 10 & 0 & 30 & 10 & 10 & 30 & 40 & 0 & 130 \\
\hline (\%) & 3.23 & 0 & 5.56 & 14.29 & 5.56 & 7.32 & 8.7 & 0 & 44.66 \\
\hline Isiekenesi & 40 & 10 & 30 & 0 & 0 & 20 & 30 & 0 & 130 \\
\hline (\%) & 12.9 & 10 & 5.56 & 0 & 0 & 4.88 & 6.52 & 0 & 39.86 \\
\hline Mgbidi & 20 & 0 & 30 & 0 & 10 & 40 & 10 & 20 & 130 \\
\hline (\%) & 6.45 & 0 & 5.56 & 0 & 5.56 & 9.76 & 2.17 & 7.41 & 36.91 \\
\hline Nguru & 0 & 0 & 30 & 20 & 20 & 30 & 10 & 20 & 130 \\
\hline Nwenkwo & & & & & & & & & \\
\hline (\%) & 0 & 0 & 5.56 & 28.57 & 11.11 & 7.32 & 2.17 & 7.41 & 62.14 \\
\hline Nkwerre & 40 & 10 & 50 & 0 & 20 & 0 & 10 & 0 & 130 \\
\hline (\%) & 12.9 & 10 & 9.26 & 0 & 11.11 & 0 & 2.17 & 0 & 45.44 \\
\hline Oguta & 0 & 0 & 60 & 0 & 0 & 30 & 0 & 40 & 130 \\
\hline (\%) & 0 & 0 & 11.11 & 0 & 0 & 7.32 & 0 & 14.81 & 33.24 \\
\hline Okuku & 20 & 10 & 30 & 0 & 0 & 20 & 40 & 10 & 130 \\
\hline (\%) & 6.45 & 10 & 5.56 & 0 & 0 & 4.88 & 8.7 & 3.7 & 39.29 \\
\hline Okwelle & 20 & 0 & 10 & 20 & 10 & 30 & 20 & 20 & 130 \\
\hline (\%) & 6.45 & 0 & 1.85 & 28.57 & 5.56 & 7.32 & 4.35 & 7.41 & 61.51 \\
\hline Orodo & 20 & 10 & 20 & 0 & 20 & 30 & 30 & 0 & 130 \\
\hline (\%) & 6.45 & 10 & 3.7 & 0 & 11.11 & 7.32 & 6.52 & 0 & 45.10 \\
\hline Orsu Obodo & 0 & 0 & 30 & 0 & 10 & 0 & 50 & 40 & 130 \\
\hline (\%) & 0 & 0 & 5.56 & 0 & 5.56 & 0 & 10.9 & 14.81 & 36.83 \\
\hline Otulu & 10 & 0 & 10 & 1010 & 40 & 30 & 20 & 130 & \\
\hline (\%) & 3.23 & 0 & 1.85 & 14.29 & 5.56 & 9.76 & 6.52 & 7.41 & 48.62 \\
\hline Owerri & 40 & 20 & 40 & 0 & 10 & 10 & 0 & 10 & 130 \\
\hline Nkwoji & & & & & & & & & \\
\hline (\%) & 12.9 & 20 & 7.41 & 0 & 5.56 & 2.44 & 0 & 3.7 & 52.01 \\
\hline Umuguma & 20 & 20 & 20 & 10 & 0 & 10 & 30 & 20 & 130 \\
\hline (\%) & 6.45 & 20 & 3.7 & 14.29 & 0 & 2.44 & 6.52 & 7.41 & 60.81 \\
\hline Umuna & 10 & 0 & 40 & 0 & 0 & 20 & 30 & 30 & 130 \\
\hline (\%) & 3.23 & 0 & 7.41 & 0 & 0 & 4.88 & 6.52 & 11.11 & 33.15 \\
\hline Umunkwo & 0 & 0 & 30 & 0 & 20 & 20 & 50 & 10 & 130 \\
\hline (\%) & 0 & 0 & 5.56 & 0 & 11.11 & 4.88 & 10.9 & 3.7 & 36.15 \\
\hline
\end{tabular}

Source: Author’s fieldwork. 
In the course of this study, a number of hypotheses were propounded for testing in this research. These hypotheses included the following:

\section{Constraints of Production Inputs}

$\mathrm{H}_{0}$ : A majority of rural women in Imo State engaged in informal economic activities do not have significant access to institutional finance.

$\mathrm{H}_{1}$ : A majority of rural women in Imo State engaged in informal economic activities have significant access to institutional finance.

In testing this hypotheses an analysis of two major responses (Yes, No) as it related to the number of respondents for the study (totalling 2,340) was used (see Table 3)

Table 3: Analysis of Z-Test of Rural Women's Access to Institutional Finance

\begin{tabular}{lllll}
\hline $\begin{array}{l}\text { Access to Institutional } \\
\text { Finance }\end{array}$ & Proportion & Z Statistic & $\operatorname{Pr}>Z$ & Z Tabulated \\
\hline Yes & 0.1923 & -9.41 & 1.0000 & 1.645 \\
\hline
\end{tabular}

Source: Result of computer analysis

Table 3 is a summary of the results of the analysis. It shows that the $\mathrm{Z}$ Statistic is -9.41 . Since this is less than the $\mathrm{Z}$ Tabulated value of 1.645 , the test is not significant. Thus, we do not reject the null hypothesis $\left(\mathrm{H}_{\mathrm{o}}\right)$. Therefore a majority of rural women in Imo State engaged in informal economic activities do not have significant access to institutional finance.

This implies that only few of the rural women engaged in informal economic activities in Imo State have access to institutional finance. This is likely to arise from the fact that, of the 18 communities studied only three have near-dormant/inactive women's co-operatives, which occasionally lend women money, only one community has women who receive soft loans from oil companies and just a couple of elite rural women claim they have obtained bank loans in the past from Nigerian Agricultural and Cooperative Bank and Peoples Bank.

$\mathrm{H}_{0}$ : A majority of rural women in Imo State engaged in informal economic activities do not have significant access to farm land/business premises.

$\mathrm{H}_{1}$ : A majority of rural women in Imo State engaged in informal economic activities, have significant access to farm land/business premises. 
In testing this hypothesis, an analysis of two major responses (Yes, No) as it related to the number of respondents for the study (totalling 2, 340) was used.

Table 4: Analysis of Z-Test of Rural Women's Access to Farmland /Business Premises

\begin{tabular}{lllll}
\hline $\begin{array}{l}\text { Access to Farmland/Business } \\
\text { Premises }\end{array}$ & Proportion & Z Statistic & Pr $>$ Z & Z Tabulated \\
\hline Yes & 0.6966 & 6.01 & $<.0001$ & 1.645 \\
\hline
\end{tabular}

Source: Result of computer analysis

Table 4 is a summary of the results of the analysis. It shows that the $\mathrm{Z}$ Statistic is 6.01. Since this value is greater than the $\mathrm{Z}$ Tabulated value of 1.645, we reject the null hypothesis $\left(\mathrm{H}_{0}\right)$ and accept the alternative $\left(\mathrm{H}_{1}\right)$. That is, a majority of rural women in Imo State engaged in informal economic activities have significant access to farmland/business premises. There are more study communities with sufficient land for farming by women than those without sufficient land for farming. Many of the rural women in the study communities do not suffer gross land discriminatory cultural norms and land tenureship practices. Some communities have big periodic markets with sufficient stalls/stores and others without one have enough space for rural women to operate as itinerants hawkers. This explains why the alternative hypothesis was accepted.

\section{Constraints on Enhancing Facilities and Services}

$\mathrm{H}_{0}$ : Rural women in Imo State do not have significant access to socio-economic services that enhance women's informal economic activities.

$\mathrm{H}_{1}$ : Rural women in Imo State have significant access to socio-economic services that enhance women's informal economic activities.

In testing this hypothesis, an analysis of two major responses (Yes, No) as it related to the number of respondents for the study (totalling 2,340) was used.

\section{Table 5: Analysis of Z-Test of Rural Women's Access to Socio-Economic Services}

\begin{tabular}{lllll}
\hline $\begin{array}{l}\text { Access to Socio- Economic } \\
\text { Services }\end{array}$ & Proportion & Z Statistic & Pr $>Z$ & Z Tabulated \\
\hline Yes & 0.4188 & -2.48 & 0.9935 & 1.645 \\
\hline
\end{tabular}

Source: Result of computer analysis 
Table 5 is a summary of the results of the analysis. It shows that Z-calculated as -2.48. Since the Z Statistic value is less than the Z Tabulated value of 1.645, the test is not significant. That is, we do not reject the null hypothesis $\left(\mathrm{H}_{0}\right)$. Thus, a majority of rural women in Imo State do not have significant access to socio-economic services that enhance women's informal economic activities. This is because in most of the communities with an electricity supply, the supply is in fact erratic and not very regular. Many villages suffer from broken-down transformers that are ill maintained, except when the people through self-help rally round to effect repairs themselves. In many communities with boreholes, the boreholes frequently break down owing to age and lack of maintenance, while their service reservoirs are mere monuments adorning the rural landscape. Despite the presence of electricity and a potable water supply, the rural women still suffer from water/light inadequacy. Electricity bills and water rates are hardly affordable as a result of the predominance of low incomes. And government health services are rarely obtained at affordable charges. That is to say, the presence of socio-economic facilities in some of the communities does not necessarily translate to the fact that those services are provided as they ought to be. This thus distinguishes the presence of socio-economic facilities from access to socioeconomic services.

\section{$\mathrm{H}_{0}$ : Rural areas in Imo State do not have significant presence of socio-economic facilities that enhance women's informal economic activities.}

$H_{i}$ : Rural areas in Imo State have significant presence of socio-economic facilities that enhance women's informal economic activities.

In testing this hypothesis, an analysis of two major responses (Yes, No) was used as it related to the number of respondents for the study (totalling 2, 340).

Table 6: Analysis of Z-Test of Presence of Socio-economic Facilities in the Rural Area

\begin{tabular}{lllll}
\hline $\begin{array}{l}\text { Presence of Socio-Economic } \\
\text { Facilities }\end{array}$ & Proportion & Z Statistic & $\operatorname{Pr}>Z$ & Z Tabulated \\
\hline Yes & 0.6325 & 4.05 & $<.0001$ & 1.645 \\
\hline
\end{tabular}

Source: Result of computer analysis

Table 6 is a summary of the results of the analysis. It shows that the Z Statistic is 4.05. Since this value is greater than the $\mathrm{Z}$ Tabulated value of 1.645 , then the test is significant at $5 \%$ level. Thus, we reject the null hypothesis $\left(\mathrm{H}_{0}\right)$ and 
accept the alternative $\left(\mathrm{H}_{1}\right)$. This means that a majority of rural areas in Imo State have significant presence of socio-economic facilities that enhance rural women's informal economic activities. Actually, many of the study communities have some level of presence of socio-economic facilities, namely: good access roads, good schools, hospitals and health facilities, bank and post office. This result only confirms the availability of socioeconomic facilities that ought to enhance their activities as earlier stated, but questions their accessibility. This is because for one reason or another most of the rural people do not utilize these facilities at all or rather do not utilize them to their fullest. Some of these facilities that functioned in the past are not functional now or where functional are unaffordable by the great majority. And this invariably constrains rural women's informal economic activities, which range from food processing to vocational/handicraft activities in the study area.

\section{Policy Implications}

What is the policy significance of this research? It is known that Nigeria has created a bias in the policy framework in favour of the formal sector. This may be attributed to the belief of the government that modernization is synonymous with development, or it may be attributed to insufficient awareness of and information on this sector. The bias is sometimes attributed to the existence of a formal sector 'lobby', which has privileged access to policymaking in the government. In Nigeria policies are not specifically designed for the informal sector; furthermore the absence of such policies can have a negative effect on the informal sector, by limiting participation in it and constraining responses to opportunities for expansion but distorting the incentive structures.

It is essential that policies be so designed as to encourage the effective participation of the informal sector in development. The primary reason for creating a supportive policy framework lies in the promotion of efficiency and growth in the overall economy. These policies, besides increasing the demand potential for informal sector output, may also contribute to faster transformation of the units concerned: policies favouring technological transfer and upgrading, closer linkages with modern sector firm and trading policies etc.

As part of the evidence from this study, there is an expressed desire by the rural women engaged in informal economic activity to earn higher income in the village. We then come to the conclusion that in order to improve the standard of living in rural Nigeria, Federal Government policies and programmes for small and medium-scale enterprises should be re-engineered 
and vigourously pursued in both the urban and rural areas of the country, or At the least policy changes should be made to ease constraints.

There are at least four reasons why policymakers in Nigeria should pay greater attention to the rural informal sector: resource allocation; income disparities, due to market imperfections; rural poverty; and the rapid expansion of the sector. The policies and programmes of Industrial Development Centres (IDCs), the Nigerian Bank for Commerce and Industries (NBCI), the National Directorate of Employment (NDE), The Peoples Bank of Nigeria (microfinance bank), community banks, NERFUND, Central Bank of Nigeria/World Bank-Assisted SME Loan Scheme and State Programmes should be revised.

There are available proposals on how to achieve these laudable objectives (Obadan et al. 1995). They include improving accessibility to product markets, improving and strengthening liquidity and the capital base, strengthening the infrastructural base, adding flexibility in the regulatory framework, strengthening training and technical capability, and the promotion of welfare programmes and development of informal sector organizations. We suggest that a concerted effort on enhancing rural women's informal economic activities in Imo State in its interrelated forms mounted by government agencies through a policy of citizen participation, especially women's participation, can do much to improve the rural living standards.

\section{Policy Recommendations}

Policies that eliminate restrictions that currently prevent rural women's informal enterprises from participating in public bids for supplies, and those that promote subcontracting arrangements between informal and formal operators. to ensure expanded markets and upgrade the technological capacity in the informal sector, are highly recommended.

\section{Conclusion}

The investigation revealed that petty commodity production and commerce is an important sector in Nigeria's rural economy. Rural women's participation in this sphere has increased owing to the harsh economic realities prevalent in the nation. The study further showed that though rural women are engaged in a number of income-generating activities, these activities are hampered by a multitude of constraints. Rural women should acquire relevant vocational skills, which the government can provide through mobile training institutions tagged 'schools on wheels'.

This study shows that the rural women are faced with several problems in their means of livelihood. These problems significantly affect rural women's informal economic activities in the study area. Notable among them are lack of access to institutional finance, inadequate credit facilities, low capital, 
lack of access to socio-economic facilities/services and poor development/ maintenance of infrastructure, among others.

Hence, for poverty reduction, reduction in rural-urban migration and overall development of the rural parts of Imo State, these constraints must be drastically reduced. Generally, this can be achieved through the strengthening of women's ministries and agencies, the creation of functional and efficient formal and non-formal financial institutions, the strengthening of the rural infrastructural base, the modification of the legal and institutional framework, and more efficient policy/programme formulation and implementation by the government and donor agencies.

\section{References}

Abumere, S. I., 1995, 'The Informal Sector: Methodological and Policy Challenges', paper presented at a Departmental Seminar, Department of Geography, University of Ibadan, 8 December .

Aluko, S. A., 1980, 'The Management of Rural Economy', Management in Nigeria (Nigerian Institute of Management, Lagos), pp. 6-11.

Anozie, U. C. and Onwumere, J. O. J., 1988, 'Public Utilities and the Rural Areas in Imo State', in U.M. Igbozurike, ed., Critical Issues in Rural Development, Owerri: Kartopress.

Arnfred, S., 2004, Re-thinking Sexualities in Africa, Uppsala: Nordiska Afrikainstitutet.

Barlowe, R., 1978, Land Resource Economics, Englewood Cliffs, NJ: Prentice Hall Inc.

Brand, V., Mupedziswa, R. and Gumbo, P., 1995, 'Structural Adjustment, Women and Informal Sector Trade in Harare', in P. Gibbon, ed., Structural Adjustment and the Working Poor in Zimbabwe, Uppsala: Nordiska Afrikainstitutet.

Crowley, E., 1995, 'Rural Institutions and Choice: Alternative Approaches to Resource Access and Allocation for Technology Adoption in African Agriculture', paper presented to the Rockefeller Foundation CGIAR Meetings, Addis Ababa, November.

Damson, J. and Oyeyinka, B., 1993, 'Structural Adjustment and the Urban Informal Sector in Nigeria', WEP 2-19, WP65, Geneva: International Labour Organization.

Dietrich, G., 1995, 'Women's Struggle for Production of Life: Public Hearings of Women Workers in Informal Sector', Economic and Political Weekly XXX(26): $1551-4$.

Eboh, E. C. and Ocheoha, K. N., 2002, 'Determinants of Rural Non-Farm Sector Potential in Reducing Income-Poverty: Evidence from Enugu State, Nigeria', Proceedings of 36th Annual Conference of Agricultural Society of Nigeria, FUT, Owerri, 20-24 October, pp. 160-4. 
Eze, D. N. and Okoli, E. C., 1995, ‘Female Farmers’ Access to Technological Imputs in Nsukka’, in M.O. Osita, B. O. Oreyinka and E. Miawa, eds, Technology, Policy and Practice in Africa, Nairobi, Kenya: IDRC.

Eze, S. O., 2002, 'Post-Harvest Plantain Technology Dissemination and Agricultural Extension Implications for Poverty Eradication among Rural Women in Anaocha Local Government Area of Anambra State', Proceedings of 36th Annual Conference of Agricultural Society of Nigeria, FUT, Owerri, 20-24 October, pp. 201-4.

FAO (Food and Agricultural Organization of the United Nations) (1999) Highland Level Consultation on Rural Women and Information, Land Tenure Service, Rome: FAO.

Federal Government of Nigeria, 1993, Final Report on a Study of the Informal Sector of the Nigerian Economy Submitted to the National Planning Commission by Resman Associates Limited, Lagos.

Feldman, S., 1991, 'Still Invisible: Women in the Informal Sector', in R.S Gallin and A.Ferguson, eds, The Women and International Development Annual, Volume 2, Boulder, CO: Westview Press.

Gerry, C., 1978, 'Petty Production and Capitalist Production in Dakar: The Crisis of the Self Employed’, World Development Journal 6(9-10).

Goodale, G., 1989, 'Training for Women in the Informal Sector: The Experience of the Pathfinder Fund in Latin America and the Carribbean', in F. Fluitman, ed., Training for Work in the Informal Sector, Geneva: International Labour Office.

Hemmer, H. and Manuel, C., 1989, 'On the Economic Analysis of the Urban Informal Sector', World Development Journal 17(10).

Igbozurike, U. M., 1985, 'Rural Water Supply problems in Parts of Imo State, Nigeria', paper presented at the 28th Annual Conference of the Nigerian Geographical Association, University of Lagos, Lagos, 31 March-4 April.

Igbozurike, U. M., 1986, ‘Cooperative Farming Practices’, in O. Okereke, ed., Cooperatives and the Nigerian Economy, Nsukka: University of Nigeria Press

Ijere, M. O., 1992, Leading Issues in Rural Development, Enugu, Lagos, and Los Angeles: Acena Publishers.

International Labour Organization, 1985, Informal Sector in Africa: Job and Skills Programme for Africa, Addis Ababa: ILO.

Malunga, J. S., 1998, 'Women Employees in the Informal Sector, Kampala, Uganda’, Gender Issues Research Series 8, Addis Ababa: OSSREA.

Mate, R., 2005, Making Ends Meet at the Margins?: Grappling with Economic Crisis and Belonging in Beitbridge Town, Zimbabwe, Dakar: CODESRIA.

McNeil, M., 1993, 'Urban Entrepreneurs and the Real Economy', The Urban Age $1(2)$.

Nwebo, O. E. and Eze, O., 1989, ‘Widowhood Practices: Laws and Customs’, paper presented at a workshop on Widowhood Practices, Owerri, Imo State.

Nyamnjoh, F. B., 2005a, Insiders and Outsiders: Citizenship and Xenophobia in Contemporary Southern Africa, Dakar: CODESRIA/London: Zed Books. 
Nyamnjoh, F. B., 2005b, 'Fishing in Troubled Waters: Disquettes and Thiofs in Dakar', Africa 75(3): 295-324.

Obadan, I., Odusola, A. P. and Akerele, W. O., 1996, 'Strategies for Revitalizing the Nigerian Economy: The Role of the Informal Sector, paper presented at Revitalizing the Nigerian Economy workshop held by Nigerian Institute for Social and Policy Research (NISER), Ibadan.

Odurukwe, S. N. and Okorji, E. C., 2002, 'Analysis of Determinants of Savings and Capital Formation Levels of Rural Women in Abia State', Proceedings of 30th Annual Conference of Agricultural Society of Nigeria, FUT. Owerri, 20-24 October, pp. 308-10.

Ogbonna, J. U., 1988, 'Transport Constraints on Rural Development', in U.M. Igbozurike, ed., Critical Issues in Rural Development, Owerri: Kartopress.

Ogundana, B., 1970, 'Forms and Functions of Transport in the Ife Region', in S.A. Agboola, ed., The Ife Region, Occasional Publication No. 1, Department of Geography, University of Ife, Ile-Ife, pp. 96-100.

Olayide, S. O., Ogunfowora, O., Essang, S. M. and Idachaba, F. S., 1975, Elements of Rural Economics, Ibadan: University Press

Saitao, K. A. and Spurling, D., 1992, Developing Agricultural Extension for Women Farmers, Washinton D.C.: World Bank.

Schaffer, R., Mendenhall, W. and Ott, L., 1979, Elementary Survey Sampling, North Scituate, MA: Duxbury Press.

Soetan, R. O, 1993, Technology and Women's Ventures in Nigeria's Urban Informal Sector, New York: Carnegie Corporation.

United Nations Economic Commission for Africa (UNECA) and AAPAM, 1992, Mobilizing the Informal Sector and Non-governmental Organizations (NGOs) for African Economic Recovery and Development: Policy and Management Issues, Report of the 12th AAPAM Round Table Conference, Abuja. 
